\title{
ANALISIS MEKANISME PENENTUAN PROFIT MARGIN PEMBIAYAAN MURABAHAH LEMBAGA KEUANGAN SYARIAH
}

\author{
Universitas Yudharta Pasuruan \\ Mariatus Silfiyah, Muhammad Fahmul Iltiham, Abdillah Mundir
}

\begin{abstract}
Absract: The focus of the problem is (1) What is the mechanism for determining the selling price and profit margin in murabahah financing at Al-Yasini LKS. (2) What methods are used to determine the profit margin in murabahah financing by LKS AlYasini. (3) What are the factors that affect the profit margin on murabahah financing at Al-Yasini LKS. The objectives in writing this thesis have a purpose, namely: (a) To discount the selling price and profit margin on murabahah financing at LKS Al-Yasini. (b) To discuss the method in determining the selling price and profit margin carried out by LKS Al-Yasini. against murabahah financing. (c) To discuss the factors that affect the profit margin in murabahah financing at LKS Al-Yasini.

This type of research is the researcher uses a qualitative approach and analysis techniques using descriptive methods by analyzing the data that has been obtained is qualitative, the sample data obtained is from primary data which is directly obtained from LKS Al-Yasini regarding the policy of determining murabahah profit margins. , and from secondary data which is processed data whose source can be trusted and scientifically accounted for by conducting literature studies, interviews, the internet, and others.

The research result in this thesis is the method in determining the margin carried out by LKS Al-Yasini using themethod flat, where themethod flat is the calculation of the profit margin against the cost of cost of financing on a regular basis from one period to another, even though the debit balance decreases as a result of the installments. cost of goods sold. The factors that affect the selling price and profit margin made at Al-Yasini LKS are firstly related to the time period. second is related to the use of funds. third Related to the customer's condition.
\end{abstract}

Keywords: Profit Margin, Murababah

\section{Pendahuluan}

Peran bank sangat besar dalam mendorong pertumbuhan ekonomi suatu negara termasuk di Indonesia. Semua sektor usaha baik sektor industri, perdagangan, pertanian, perkebunan, jasa, perumahan dan lainnya sangat membutuhkan bank sebagai mitra dalam mengembangkan usahanya sesuai dengan salah satu fungsi bank yaitu pembiyaan.

Menurut Undang-Undang No.21 tahun 2008 tentang Perbankan Syariah adalah segala sesuatu yang menyangkut tentang Bank Syariah dan Unit Usaha 
Syariah, mencakup kelembagaan, kegiatan usaha, serta cara dan proses dalam melaksanakan kegiatan usahanya.Bank adalah badan usaha yang menghimpun dana dari masyarakat dalam bentuk Simpanan dan menyalurkannya kepada masyarkat dalam bentuk kredit dan/atau bentuk lainnya dalam rangka meningkatkan taraf hidup rakyat. ${ }^{1}$

Bank memiliki tiga fungsi utama, yaitu melakukan aktivitas dalam penghimpunan dana terhadap pihak ketiga, aktivitas penyaluran dan kepada pihak yang membutuhkan dana, dan aktivitas dalam memberikan pelayanan jasa kepada masyarakat. Dari ketiga fungsi tersebut, bank dapat mengembangkan usahanya dalam berbagai macam bentuk produk bank, yaitu produk yang terkait dengan penghimpunan dana, penyaluran dana dan pelayanan jasa. $^{2}$

Praktik ekonomi syariah di Indonesia saat ini mulai berkembang karena minat umat Islam yang ingin terhindar dari bunga dalam bank konvensional. faktor lain yaitu karena sebagian besar penduduk Indonesia mayoritas beragama Islam. Minat tersebut semakin berkembang seiring dengan berkembangnya upaya pemahaman terhadap kegiatan kegiatan ekonomi yang berlandaskan syariah Islam pada awal tahun 1990-an, yaitu ditandai dengan dibentuknya secara kelembagaan Bank Muamalat Indonesia pada tahun 1992.

Seiring berkembangnya zaman di era globalisasi seperti sekarang ini membuat seluruh sektor dunia usaha ingin terus maju dan berkembang, dikarenakan banyaknya persaingan dan munculnya pasar bebas yang tidak bisa dihindari oleh bangsa Indonesia. Lembaga Keuangn Syariah merupakan salah satu usaha yang juga mengalami dampak dari globalisasi. Hal ini dikarenakan Lembaga Keuangan Syariah berperan penting dalam mendorong pertumbuhan ekonomi.

Lembaga Keuangan Syariah (LKS) merupakan salah satu jenis lembaga keuangan yang dikenal melayani golongan pengusaha mikro, kecil dan menengah. Lembaga Keuangan Syariah (LKS) Al Yasini merupakan salah satu sektor perbankan yang dituntut mampu bersaing dengan LKS-LKS lainnya. Salah satu kegiatan utama dan sumber pendapatan bagi Lembaga Keuangan Syariah (LKS) Al Yasini adalah memberikan pinjaman kredit. Dalam kegiatan operasionalnya Lembaga Keuangan Syariah (LKS) Al Yasini menghadapi persaingan yang sangat ketat dengan lembaga keuangan lain seperti BMT dan BPR. Penyaluran kredit yang diberikan Lembaga Keuangan Syariah (LKS) Al Yasini supaya terlaksana dengan baik maka pihak manajemen LKS harus dapat mengambil keputusan yang tepat dalam suatu pemberian kredit kepada calon nasabah.

\footnotetext{
${ }_{1}^{1}$ Irham Fauzi, Bank Dan Lembaga Keuangan Lainnya: Teori Dan Aplikasi.(Bandung: Alfabeta, 2014), 2.

2 Ismail, Akuntansi Bank: Teori Dan Aplikasi Dalam Rupiah (Jakarta: Kencana, 2010), 12.
} 
Namun yang menarik, ada sebuah pernyataan yang dikatakan oleh seorang tokoh yang bernama Umar Vadillo, beliau adalah seorang cendekiawan muslim Eropa yang cerdas dan teguh pendirian,yang menyatakan "Bank tetap haram. Dan bagaimanapun juga bank syariah tetap haram". Menurutnya, Bank syariah adalah lembaga ribawi yang bertentangan dengan Islam. Sejak kehadirannya bank syariah telah dibina dan dipromosikan para pelaku riba untuk menjaring dana umat muslim seluruh dunia kedalam sistem moneter dan keuangan internasional. Secara tidak sadar mereka telah dikendalikan dan masuk dalam lingkaran sistem capitalisme global. ${ }^{3}$

Seorang mantan pejabat Bank Indonesia pernah mengatakan "Bank syariah pada dasarnya sama dengan bank konvensional, dikurangi bunga, ditambah jilbab. Meskipun terdengar nyinyir, inilah tantangan bank syariah yang sebenarnya bagaimana membuat bank syariah lebih fokus pada pembiayaan bagi hasil dan berjangka panjang pada sektor-sektor yang berorientasi pertumbuhan untuk meningkatkan kesejahteraan masyarakat. ${ }^{4}$

Masalahnya, prinsip syariah belum tentu sepenuhnya dijalankan oleh Bank-bank syariah yang ada di indonesia. Prinsip pembiayaan bagi hasil di perbankan syariah masih rendah. Bank-bank syariah pada umumnya telah menggunakan murabahah sebagai metode pembiayaan mereka yang utama, meliputi kira-kira tujuh puluh lima persen dari total kekayaan mereka.

Secara teknis yang dimaksud dengan margin keuntungan adalah prosentase tertentu yang ditetapkan per tahun perhitungan margin keuntungan secara harian, maka jumlah hari dalam setahunditetapkan 360 hari; perhitungan margin keuntungan secara bulanan, maka satahun ditetapkan 12 bulan.

Pentingnya profit margin bagi perusahaan jasa yaitu untuk dapat membiayai operasional suatu perusahaan dalam pencapaian laba yang lebih maksimal, untuk dapat melunasi hutang yang ada, sebagai cadangan dana untuk suatu kebutuhan investasi perusahaan, untuk perkembangan suatu perusahaan dimasa yang akan datang.

Biaya operasional perbankan mempertimbangkan profit margin agar proses usaha yang dilakukan oleh perusahan berjalan lancar. Berangkat dari latar belakang tersebut maka penulis tertarik untuk mengadakan penelitian ilmiah dengan judul:"Analisis Mekanisme Penentuan Profit Margin Pembiayaan Murabahah Di Lembaga Keuangan Syariah (Lks) Al Yasini"

\footnotetext{
${ }^{3}$ Umar Vadillo, The End of Economics: An Islamic Critique of Economics, Terj. Sigit Kurnadi Dan Tri Joko S. -Bank Islam Tetap Haram; Kritik Terhadap Kapitalisme, Sosialisme Dan Perbankan Syariah.(jakarta: Pustaka Zaman, 2005), 113.

${ }^{4}$ Ahmad Dwi Haryoso, Studi Analisis Terhadap Pemikiran Muhammad Syafi"i Antonio Tentang Murabahah Dalam Perspektif Hukum Islam.(2005): 25.
} 


\section{Kajian Pustaka}

\section{Lembaga Keungan Syari'ah}

Lembaga keuangan syariah (LKS) adalah lembaga yang dalam aktifitasnya, baik penghimpunan dana maupun dalam rangka penyaluran dananya memberikan dan mengenakan imbalan atau dasar prinsip syariah yaitu jual beli dan bagi hasil. ${ }^{5}$

Perkembangan Bank dan Lembaga Keuangan Syariah di Indonesia mengalami peningkatan baik dari segi kuantitas maupun jenisnya. Perbankan syariah yang mulai beroperasi di Indonesia pada tahun 1992 dengan berdirinya Bank Muamalat dan disusul dengan Asuransi Syariah Takaful yang didirikan pada tahun 1994. Kedua lembaga keuangan syariah tersebut bisa katakan menjadi pionir tumbuhnya bisnis syariah di Indonesia. Pada awal berdirinya, bukan hal yang mudah untuk memperkenalkan bisnis syariah di Indonesia walaupun mayoritas penduduk Indonesia dalah muslim. Mulai dari istilah yang cukup sulit dihafalkan, sampai dengan konsep operasional yang dirasakan berbelit-belit.

\section{Mekanisme}

Mekanisme menjadi satu kata yang teramat sering digunakan saat ini. Ada banyak pengertian tentang mekanisme dengan konteks yanf berbeda. Pada dasarnya, mekanisme berasal dari Bahasa Yunani mechane yang berartu instrument, mesin perangkat beban, perlatan yang digunakan untuk membantu sesuatu dan juga pernagkat. mekanisme juga berasala dari kata mechos yang berarti sarana serta cara untuk menjalankan sesuatu.

Pengertian yang pertama, mekanisme dalam dunia teknik menurut KBBI. Mekanisme dalam dunia teknik memiliki ari penggunaan mesin, alat-alat dari mesin, hal kerja mesin. Lebih jelasnya, mekanisme dalam dunia teknik digunkan untuk menjelsakan sebuahh teori yang berhbugan dengan gejala yang diperinci dengan menggunakan prinsip-prinsip yang bisa digunkan dalam menjelaskan sistem kerja mesin-mesin tanpa menggunakan bantuan intelegensi sebuah sebab ataupun juga prinsip kerja.

\section{Profit Margin}

Bank Syari'ah atau lembaga keuangan syari'ah sebagai penjual dalam menawarkan harga jual berdasarkan harga pokok yang diberitahukan secara jujur ditambah dengan keuntungan yang diharapakan oleh bank dari nasabah yang bertindak sebagai pembeli. Sedangkan pembeli melakukan penawaran sebesar harga pokok ditambah dengan keuntungan yang dinginkan oleh nasabah.

Proses penentuan nisbah bagi hasil pembiyaan ini ditentukan dengan mempertimbanhkan hal-hal sebagai berikut:

\footnotetext{
${ }^{5}$ Muhammad abdul karim,kamus bank syariah (Yogjakarta : asnaliter) Hal. 32
} 
a) Tingkat keuntungan yang diharapkan pihak bank. Hal ini dipengaruhi oleh beberapa komponen yang dapat disesuaikan dengan kebutuhan pasar meliputi :

1) Beban dana operasional

Merupakan beban dana operasional yang langsung dikeluarkan bank untuk memperoleh sejumlah dana tertentu dari para shohibul maal, baik untuk simpanan giro, tabungan ataupun deposito berjangka.

2) Beban dana efektif

Merupakan beban dana operasional yang dikeluarkan bank setelah diperhitungkan dengan cadangan likuiditas wajib minimum.

3) Beban Overhead

Komponen yang diperhitungkan dalam beban overhead ini masih terdapat perbedaan presepsi di antara para banker's, namun demikian pengelolaan penyaluran dalam rangka pengelolahan penyaluran pembiyaan sepatutnya diperhitungkan sebagai beban overhead.

4) Beban dana

Merupakan beban dana efektif setelah ditambah dengan beban overhead.

5) Margin (Laba yang Diinginkan)

Setiap bank melakukan transaksi selalu menginginkan memperoleh laba yang maksimal atau optimal. penetapatan laba yang diinginkan ini memerlukan perhitungan dan pertimbangan yang matang, karena akan berakibat pada tingkat margin/imbal bagi hasil menjadi tinggi. Dalam menetapkan margin juga memperhatikan kondisi persaingan, kondisi nasabah serta menurut jenis proyek yang dibiayai.

Angsuran harga jual terdiri dari angsuran harga beli/harga pokok dan angsuran margin keuntungan. Pengakuan angsuran dapat dihitung dengan menggunakan empat metode yaitu:

1) Metode margin keuntungan menurun(sliding)

Margin keuntungan menurun adalah perhitungan margin keuntungan yang semakin menurun sesuai dengan menurunnya harga pokok sebagai akibat adanya cicilan/angsuran harga pokok, jumlah angsuran (harga pokok dan margin keuntungan) yang dibayar nasabah setiap bulan semakin menurun.

2) Margin keuntungan rata-rata

Margin keuntungan rata-rata adalah margin keuntungan yang perhitungannnya secara tetap dan jumlah angsuran (harga pokok dan margin keuntungan) dibayar nasabah tetap setiap bulan.

3) Margin keuntungan flat

Margin keuntungan flat adalah perhitungan margin keuntungan terhadap nilai harga pokok pembiayaan secara tetap dari satu periode ke periode lainnya, walaupun baki debetnya menurun sebagai akibat dari adanya angsuran harga pokok. 
4) Margin keuntungan annuitas

Margin keuntungan annuitas adalah margin keuntungan yang diperoleh dari perhitungan secara annuitas. Perhitungan annuitas adalah suatu cara pengembalian pembiayaan dengan pembayaran angsuran harga pokok dan margin keuntungan secara tetap. Perhitungan ini akan menghasilkan pola angsuran harga pokok yang semakin membesar dan margin keuntungan semakin menurun.

\section{Pembiayaan}

Pembiyaan dalam perbankan syari'ah atau istilah teknisnya aktiva produktif, menurut ketentuan Bank Indonesia adalah penanaman modal Bank Syrari'ah baik dalam rupiah maupun valuta asing dalam bentuk pembiyaan, piutang, qard, surat berharga syari'ah, penempatan, penyertaan modal, penyertaan modal sementara, komitmen dan kontijensi pada rekening administrative serta sertifikat wadiah Bank Indonesia. ${ }^{6}$

Pembiayaan adalah penyediaan dana atau tagihan yang dipersamakan dengan itu berupa:

a) transaksi bagi hasil dalam bentuk mudharabah dan musyarakah;

b) transaksi sewa-menyewa dalam bentuk ijarah atau sewa beli dalam bentuk ijarah muntahiya bittamlik.

c) transaksi jual beli dalam bentuk piutang murabahah, salam, dan istishna';

d) transaksi pinjam meminjam dalam bentuk piutang qardh; dan transaksi sewa-menyewa jasa dalam bentuk ijarah untuk transaksi multijasa

\section{Akad}

Akad menurut Hasbi Ash-Shiddieqy, bahwa pengertian akad atau perikatan adalah mengumpulkan dua tepi/ujung tali yang mengikat salah satunya dengan yang lain hingga bersambung, lalu keduanya menjadi sepotong benda. $^{7}$

Definisi lain akad menurut istilah adalah: pertalian ijab dan qabul sesuai dengan kehendak syariat yang berpengaruh pada objek perikatan. Yang dimaksud "sesuai dengan kehendak syariat" adalah bahwa seluruh perikatan yang dilakukan oleh dua belah pihak atau lebih, apabila tidak sejalan dengan kehendak syara', misalnya kesepakatan untuk melakukan transaksi riba, menipu orang lain, atau merampok kekayaan orang lain. Sementara yang dilakukan "berpengaruh pada objek perikatan" adalah terjadinya perpindahan pemilikan suatu pihak (yang melakukan ijab) kepada pihak yang lain (yang menyatakan qabul). ${ }^{8}$

\footnotetext{
${ }^{6}$ Muhammad, Manajemen Dana Bank Syariah(jakarta: Rajawali Pers, 2014), 302.

${ }^{7}$ TM Hasbi Ash-Shiddieqy, Pengantar Fiqh Muamalah, Ed. 2 (Semarang: Pustaka Rizki Putra, (1997), h.19.

${ }^{8}$ Abdul Azis Dahlan, Ensiklopedi Hukum Islam, Jilid I, h. 63
} 
Analisis Mekanisme Penentuan Profit Margin Pembiayaan Murabahah Lembaga Keuangan Syariah 


\section{Murabahah}

Akad murabahah adalah transaksi jual beli suatu barang sebesar harga perolehan barang ditambah dengan margin yang telah disepakati oleh para pihak, dimana penjual menginformasikan terlebih dahulu harga perolehan kepada pembeli.

Dalam penyaluran pembiyaan berdasarkan akad murabahah, Undangundang perbankan syariah memberikan penjelasan bahwa yang dimaksud dengan Akad Murabahah adalah akad pembiyaan suatu barang dengan menegaskan harga belinya kepada pembeli dan pembeli membayarnya dengan harga yang lebih sebagai keuntungan yang disepakati. ${ }^{9}$

Dalam bai' al-murabahah, penjual harus memberitahu harga produk yang ia beli dan menentukan suatu tingkat keuntungan sebagai tambahannya. Misalnya, pedagang eceran membeli computer dari grosir dengan harga Rp. 10.000.000,- kemudian ia menambahkan keuntungan sebesar RP.750.000,dan ia menjual kepada si pembeli dengan harga Rp.10.750.000,- .

Pada umumnya, si pedagang eceran tidak akan memesan dari grosir sebelum ada pesanan dari calon pembeli dan mereka sudah menyepakati tentang lama pembiyaan, besar keuntungan yang akan diambil pedagang eceran, serta besarnya angsuran kalua memang kan dibayar secara angsuran. ${ }^{10}$

\section{Metodologi Penelitian}

Jenis penelitian yang digunakan pada penelitian ini adalah penelitian kualitatif. Penelitian kualitatif adalah penelitian yang menghasilkan data deskriptif berupa kata-kata tertulis atau lisan dari orang-orang dan perilaku yang dapat diamati. ${ }^{11}$

Sedangkan pendekatan penelitian ini adalah pendekatan studi kasus merupakan studi yang mendalam hanya pada satu kelompok orang atau peristiwa. Teknik ini hanyalah sebuah deskripsi terhadap individu. ${ }^{12}$

\section{Data dan Sumber Data}

Dalam penelitian ini, penulis menggunakan dua jenis data yaitu data primer dan data sekunder.

a. Data primer

Data Primer adalah sumber data yang langsung memberikan data kepada pengumpul data. ${ }^{13}$ Dalam penelitian ini data primer yang dimaksud adalah mereka yang menjadi objek penelitian ini, yaitu wawancara secara langsung

\footnotetext{
${ }^{9}$ A Wangsawidjaja Z, Pembiayaan Bank Syariah, (Jakarta: PT. Gramedia Pustaka Utama, 2012), 200

${ }^{10}$ Muhammad Syafi'i Antonio, Bank Syariah: Dari Teori Kepraktek (Jakarta: Gema Insani Press, 2001), 101.

${ }^{11}$ Lexy J. Moleong, Metode Penelitian Kualitatif, Cet. 21" (Bandung: PT Remaja Rosdakarya, 2005), 4.

12 M. burhan Bungin, Penelitian Kualitatif, Edisi Ke-2" (jakarta: Prenada Media Group, 2007), 132.

${ }^{13}$ Sugiyono, Metode Penelitian Kuantitatif (Bandung: Alfabeta, 2010), 136.
} 
dengan orang-orang yang terlibat dalam Pembiayaan Murabahah Lembaga Keuangan Syariah (LKS) Al Yasini.

b. Data Sekunder

Data sekunder adalah sumber data yang tidak langsung memberikan data kepada pengumpul data. ${ }^{14}$ Pada penelitian ini data sekunder yang dimaksud adalah data yang diambil dari Al-Qur'an, buku, jurnal dan website yang sesuai dengan tema yang diangkat dan perlu dipertanggungjawabkan.

\section{Analisi Data}

Setelah berbagai data terkumpul, maka untuk menganalisisnya digunakan teknik analisis deskriptif, yaitu suatu metode penelitian yang ditujukan untuk menggambarkan fenomena-fenomena yang ada, yang berlangsung pada saat ini atau saat yang lampau. ${ }^{15}$

\section{Pembahasan}

1. Mekanisme Penentuan Profit Margin pembiayaan Murabahah pada Lembaga Keuangan Syariah (LKS) AI Yasini

Metode penentuan profit margin murabahah yang dilakukan oleh Lembaga Keuangan Syariah (LKS) Al Yasini adalah menggunakan metode keuntungan flat dimana perhitungan marjin keuntungan terhadap nilai harga pokok pembiayaan secara tetap dari satu periode ke periode lainnya, walaupun baki debetnya menurun sebagai akibat dari adanya angsuran harga pokok. Dibawah ini contoh jual beli murabahah yang dilakukan oleh Lembaga Keuangan Syariah (LKS) AI Yasini.

Contoh Soal :

Adapun metode perhitungannya adalah sebagai berikut :

Akad Pembiayaan

: MURABAHAH

Harga Pokok Jual

: Rp 3.000.000

Jangka Waktu Pembayaran

Angsuran Pokok

$$
: 1 \text { tahun (12 bulan) }
$$

\section{Angsuran Pokok}

Angsuran Mark-up

Pokok Mark-up

Baki Debet

Harga Jual
: Harga pokok Jual:Jumlah Bulan

$$
3.000 .000 / 12=250.000
$$

: Keuntungan Margin $\times$ Harga Pokok Jual

: $2,5 \% \times 3.000 .000=75.000$

: Angsuran pokok +Angsuran Mark-up

$: 250.000+75.000=325.000$

: Harga Jual-Angsuran Pokok

: 3.000.000-250.000

$=2.750 .000$

: Angsuran Mark-up xJumlah Bulan

\footnotetext{
${ }^{14}$ Ibid.138

${ }^{15}$ A Furchan, Pengantar Penelitian Pendidikan(Bandung: Remaja Rosdakarya, 2008), 317.
} 
TABEL 1.1

$$
: 75.000 \times 12=900.000
$$

\section{Jadwal Angsuran}

\begin{tabular}{|l|l|l|l|l|}
\hline $\begin{array}{l}\text { Angsuran } \\
\text { Ke }\end{array}$ & $\begin{array}{l}\text { Angsuran } \\
\text { Pokok }\end{array}$ & $\begin{array}{l}\text { Angsuran } \\
\text { Mark-up }\end{array}$ & $\begin{array}{l}\text { Pokok } \\
\text { Mark-up }\end{array}$ & $\begin{array}{l}\text { Baki } \\
\text { Debet }\end{array}$ \\
\hline 1 & 250.000 & 75.000 & 325.000 & 2.750 .000 \\
\hline 2 & 250.000 & 75.000 & 325.000 & 2.500 .000 \\
\hline 3 & 250.000 & 75.000 & 325.000 & 2.250 .000 \\
\hline 4 & 250.000 & 75.000 & 325.000 & 2.000 .000 \\
\hline 5 & 250.000 & 75.000 & 325.000 & 1.750 .000 \\
\hline 6 & 250.000 & 75.000 & 325.000 & 1.500 .000 \\
\hline 7 & 250.000 & 75.000 & 325.000 & 1.250 .000 \\
\hline 8 & 250.000 & 75.000 & 325.000 & 1.000 .000 \\
\hline 9 & 250.000 & 75.000 & 325.000 & 750.000 \\
\hline 10 & 250.000 & 75.000 & 325.000 & 500.000 \\
\hline 11 & 250.000 & 75.000 & 325.000 & 250.000 \\
\hline 12 & 250.000 & 75.000 & 325.000 & 0 \\
\hline Jumlah & 3.000 .000 & 900.000 & 3.900 .000 & \\
\hline & & & & \\
\hline
\end{tabular}

Sumber : Data Lembaga Keuangan Syariah (LKS) Al Yasini

Berdasarkan metode tersebut, dalam mekanisme menentukan profit margin dalam transaksi murabahah Lembaga Keuangan Syariah (LKS) membeli jaminan yang di berikan oleh nasabah, misalkan nasabah menjaminkan BPKB sepeda motor maka dalam akad nya pihak Lembaga Keuangan Syariah (LKS) membeli jaminan tersebut senilai pembiayaan yang diajukan dalam perjanjian transaksi murabahah yang dilakukan antara Lembaga Keuangan Syariah (LKS) dan nasabah menyebutkan keuntungan profit yang di bebankan serta beberapa detail relevan lain. Perjanjian tersebut diakhiri dengan kesepakatan cara membayar yaitu dengan tunai atau melalui cicilan. Pada waktu pembayaran nasabah menunaikan pembayaran kepada Lembaga Keuangan Syariah (LKS) Pembayaran ini mencakup biaya ke Lembaga 
Keuangan Syariah (LKS) dalam profit margin untuk Lembaga Keuangan Syariah (LKS).

2. Faktor-faktor yang mempengaruhi Profit Margin pada Pembiayaan Murabahah pada Lembaga Keuangan Syariah (LKS) Al Yasini.

Dalam kaitannya dengan faktor yang mempengaruhi penentuan harga jual dan profit margin dalam pembiayaan murabahah peneliti menggunakan teori yang ada diatas. Dan peneliti membandingkan yang ada di lapangan apakah ada kesamaan antara yang ada di dalam teori dengan yang ada di lapangan, kemudian peneliti melakukan wawancara dengan beberapa karyawan salah satu factor yang mempengaruhi penentuan harga jual dan menentukan profit margin dalam pembiayaan murabahah yang ada di Lembaga Keuangan Syariah (LKS) Al Yasini. Yang mempengaruhi dalam mengambil keputusan untuk menentukan harga jual dan menentukan margin adalah sebagai berikut

Dalam kaitanya dengan profit margin Bapak Syukron selaku pimpinan Lembaga Keuangan Syariah (LKS) Al Yasini menjelaskan "sebelumnya tidak ada metode khusus untuk penentuan profit margin, Karena masalahnya adalah situasional yaitu terkait dengan jangka waktu. Semakin lama jangka waktu angsuran pembiayan maka harga jual nya semakin tinggi. dikerenakan bunga di hitung setiap bulannya dan dikalkuasikan dalam berapa tahunpinjaman tersebut diajukan ". ${ }^{16}$

Dari faktor tersebut yang mempengaruhi besar kecilnya penetapan profit margin secara garis besar, sedangkan hasil wawancara dari Bapak Syukron yang ada di Lembaga Keuangan Syariah (LKS) Al Yasini bahwasanya yang mempengaruhi harga jual yaitu :

a. Jangka Waktu

Dalam waktu jatuh tempo atau udah waktunya pembayaran kembali, terutama berperan penting dalam penentuan profit margin yang diberikan. Menurut peneliti semakin tinggi resiko kredit yang akan diberikan oleh Lembaga Keuangan Syariah (LKS) Al Yasini, semakin tinggi pula Lembaga Keuangan Syariah (LKS) akan memasang tarif margin dalam pembiayaan. Dalam kaitannya dengan jangka waktu biasanya Lembaga Keuangan Syariah (LKS) akan menetapkan profit margin yang lebih rendah pada pembiayaan yang didukung oleh jaminan yang cukup, dibandingkan dengan pembiayaan yang diberikan tanpa jaminan atau jaminannya kurang meyakinkan. Hal yang sama akan dilakukan oleh Lembaga Keuangan Syariah (LKS) terhadap angsuran yang diberikan dalam jangka panjang. Semakin panjang jangka waktu pinjaman, maka akan semakin tinggi marginya, hal ini disebabkan besarnya kemungkinan resiko di masa mendatang. Demikian pula

\footnotetext{
${ }^{16}$ Bapak Syukron (Ketua) wawancara tgl 16 Mei 2020 pukul 11.00 WIB
} 
sebaliknya, jika pinjaman berjangka pendek, maka margin relative lebih rendah.

Dalam proses penentuan harga jual dimana Account officer (AO) dari Lembaga Keuangan Syariah (LKS) Al Yasini akan menyampaikan tingkat margin yang di inginkan oleh Lembaga Keuangan Syariah (LKS) Al Yasini kepada nasabah pembiayaan murabahah. Nasabah dapat menawar hanya sampai nilai margin tertentu yang tidak dapat diturunkan lagi. Seandainya nasabah ingin diturunkan lagi, maka kemungkinannya adalah nasabah tersebut ditolak, atau permohonannya ditunda sampai diputuskan oleh rapat pimpinan Lembaga Keuangan Syariah (LKS) Al Yasini.

\section{Kesimpulan}

Dalam menentukan perhitungan profit margin pembiayaan murabahah disesuaikan dengan tuntunan syariah serta menerapkan pola yang dalam sistem berdagang, apabila sudah terjadi kesepakatan menjadi nasabah atas dasar negosiasi dijelaskan harga beli yang ditambah biaya yang dikeluarkan dan ditambah keuntungan yang diperoleh Lembaga Keuangan Syariah (LKS) Al Yasini.

1. Metode dalam penentuan margin yang dilakukan Lembaga Keuangan Syariah (LKS) Al Yasini menggunakan metode Flat yang mana metode Flat adalah perhitungan margin keuntungan terhadap nilai harga pokok pembiayaan secara tetap dari satu periode ke periode lainnya, walaupun baki debetnya menurun sebagai akibat dari adanya angsuran harga pokok.

2. Adapun faktor-faktor yang mempengaruhi harga jual dan profit margin yang dilakukan di Lembaga Keuangan Syariah (LKS) Al Yasini yaitu jangka waktu pembiayaan nasabah. Semakin pendek jangka waktu nya semakin kecil profit marginya, karena perhitungan profit margin di hitung perbulan dan berlaku kelipatan tiap tahunnya. 


\section{Daftar Pustaka}

A Wangsawidjaja Z. Pembiayaan Bank Syariah,. Jakarta: PT. Gramedia Pustaka Utama, 2012.

Antonio, Muhammad Syafi'i. Bank Syariah: Dari Teori Kepraktek. 101. Jakarta: Gema Insani Press, 2001.

Ash-Shiddieqy, TM Hasbi Pengantar Fiqh Muamalah, Ed. 2 Semarang: Pustaka Rizki Putra, 1997.

Dwi Haryoso, Ahmad. Studi Analisis Terhadap Pemikiran Muhammad Syafi"i Antonio Tentang Murabahah Dalam Perspektif Hukum Islam.2005.

Fauzi, Irham. Bank Dan Lembaga Keuangan Lainnya: Teori Dan Aplikasi. 2. Bandung: Alfabeta, 2014.

Furchan, A. Pengantar Penelitian Pendidikan.

Ismail. Akuntansi Bank: Teori Dan Aplikasi Dalam Rupiah. 12. Jakarta: Kencana, 2010.

Moleong, Lexy J. Metode Penelitian Kualitatif, Cet. 21." 4. Bandung: PT Remaja Rosdakarya, 2005. 317. Bandung: Remaja Rosdakarya, 2008.

Muhammad, Manajemen Bank Syariah. 160. jakarta: Rajawali Pers, 2014.

Sugiyono. Metode Penelitian Kuantitatif. 136. Bandung: Alfabeta, 2010.

Usman, Husaini. Metodologi Penelitian Soaial. 2nd ed. jakarta: Bumi Aksar, 2009.

A. Vadillo, Umar. The End of Economics: An Islamic Critique of Economics, Terj. Sigit Kurnadi Dan Tri Joko S. -Bank Islam Tetap Haram; Kritik Terhadap Kapitalisme, Sosialisme Dan Perbankan Syariah. 113. jakarta: Pustaka Zaman, 2005 